九州大学学術情報リポジトリ

Kyushu University Institutional Repository

On the Cumulative After-Effects of Vernalization Treatment in Successive Generations of Wheat

Ikeda, Haj ime

Laboratory of Crop Husbandry, Faculty of Agriculture, Kyushu University

https://doi.org/10.5109/22821

出版情報: 九州大学大学院農学研究院紀要. 17 (1)，pp.99-104，1972-08. Kyushu University バージョン：

権利関係 : 


\title{
On the Cumulative After-Effects of Vernalization Treatment in Successive Generations of Wheat
}

\author{
H a jime Ikeda \\ Laboratory of Crop Husbandry, Faculty of Agriculture, \\ Kyushu University, Fukuoka
}

(Received December 5, $1971 \mathrm{j}$

\begin{abstract}
In this paper, the cumulative nature and reversibility of after-effects of the vernalization treatment in successive generations on the growth and the length of ear are reported. The material, spring wheat obtained from Kagoshima Agricultural Experiment Station was used. In this variety the heading period is accelerated a little by the vernalization treatment. Three important facts have emerged in regard to growth and ear length of wheat: (1) Plant height, length of flag leaf and ear length increased by the vernalization treatment. (2) These after-effects were cumulative from generation to generation reaching saturation approximately in 5 th generation. (3) These after-effects were reversible under non-treatment condition.
\end{abstract}

\section{INTRODUCTION}

There are a few reports on the so-called 'after-effects' of the environmental conditions in the developmental process of former generations in plants. Highkin (1958) reported that constant temperature was inhibitory for pea (Pisum sativum) growth and this inhibitory effect was seen even in the following generations, furthermore, the inhibitoty effect is cumulative from generation to generation reaching saturation, approximately in the 5th generation. Went (1961) reported that potato (Solanum tuberosum) tubers had varying potentials of producing tubers in the next generation depending on the growing conditions of the parent plants. Komatsuzaki et al. (1961) reported that low temperature treatment in wheat (Triticum vulgare) seems to influence the weight of plants, number of tillers, type of plant form, shooting period of leaf, size of leaf blade and the date of heading as observed in the greenhouse, however, after-effects were not quite apparent in the field. The after-effects were cumulative also. Suetsugu et al. (1967) reported that in soybean (Glycine Max) the after-effects of controlled conditions of long day, short day and high temperature were left in several characters in the following generations, at least in the succeeding three generations.

The analysis of the cumulative process of this after-effect and its direction is very important in the investigations of the variation and differentiation of plant. The author is making continued investigations on this point using spring wheat and has found that the vernalization treatment in successive generations influences the growing process and has marked cumulative effect on the pattern of transition of leaf shape of main stem (Ikeda, 1966). In this paper, the cumu- 
lative nature and reversibility of after-effect on the growth and the length of ear are being reported.

\section{MATERIALS AND METHODS}

All the experiments were performed in the field of Kyushu University. The material, spring wheat (Triticum vulgare, var. Danchikomugi) obtained from Kagoshima Agricultural Experiment Station was used. In this variety the heading period is accelerated a little by the vernalization treatment. This variety has gone through a self-pollination and selection program extending for some 15-20 years, and is relatively homozygous.

Precautions were taken to avoid selection in favor of any given environment in order to see any mutation which might occur and trace its origin. Sixty seeds of each line with experiment on cumulative after-effects were sown and 15 plants were grown in 5 pots. In each generation, the mixed seeds from the ear of each main stem of 15 plants were used in continuing the population. During these experiments $0.02 \%$ mutants with ear character have been discovered, these mutants were taken as an exception in this experiment.

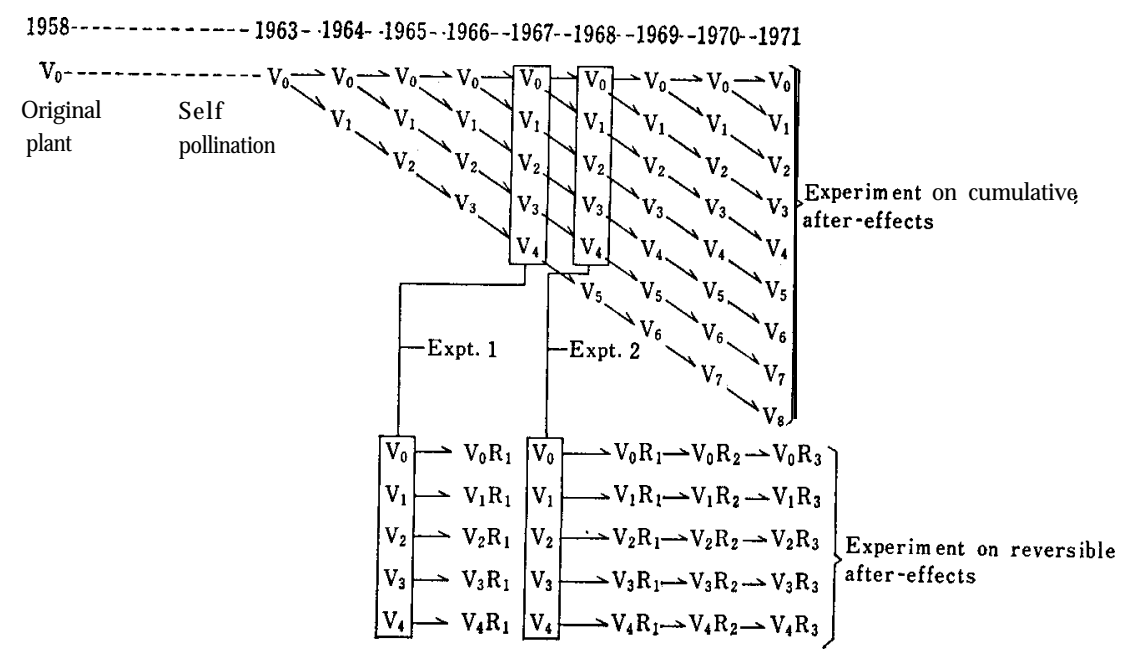

Fig. 1. Scheme of experimental lines derived from successive treatment. Vo : Non-treatment (control) line, Vn $: n$ is successive generation of vernalization treatment, $\mathrm{VnRm}: \mathrm{m}$ is successive generation of non-treatment derived Vn line.

The lines used in this experiments were derived in the way as shown in Fig. 1, viz., each line was previously treated in the following way. Seeds were vernalized for 30 days under low temperature $\left(0-2^{\circ} \mathrm{C}\right)$ and were then sown in the pots under field condition in autumn (Oct. 1). The same treatment was repeated in the successive generations.

Investigations on the reversibility of after-effects were made under the field condition. Each line (VR line) originated in experiment 1 and 2 of Fig. 1, con- 
sisted of 4 replicates and each plot contained 20 plants. Inspections were made twice, in the year 1968 and 1969-1971. The date of seeding was 1st October in both inspections. In these investigations on reversibility, the period of heading in all lines was towards the end of March and the difference in plant height, and heading date in all experimental lines was not significant.

\section{RESULTS}

(1) On the accumulation of after-effects

Plant height during March showed a steady increase in successive generations. Fig. 2 shows the relative plant height during March for $V_{0}-V_{7}$ lines in

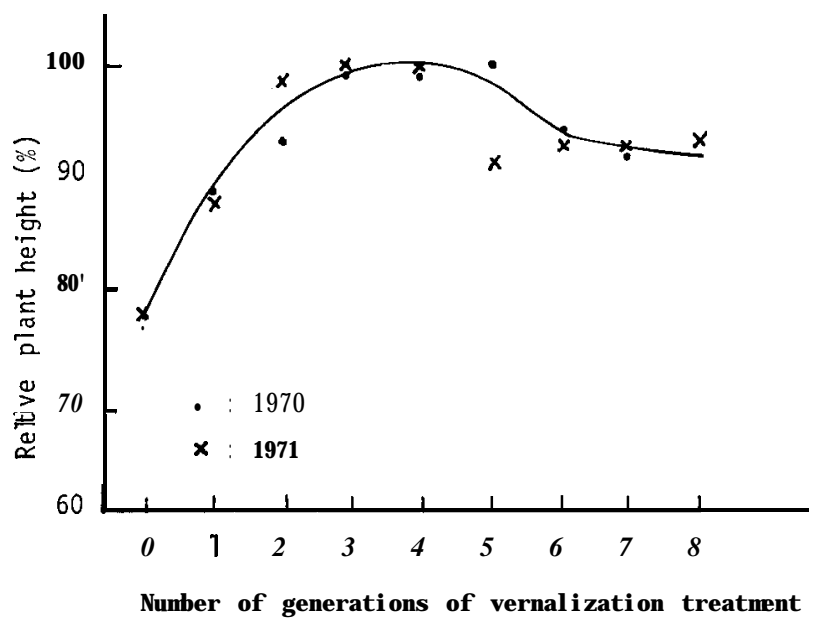

Fig. 2. Relative plant height at March in $\mathrm{V}_{0}-\mathrm{V}_{8}$ lines $(1970,1971)$.

(Max. plant height $=100$ )

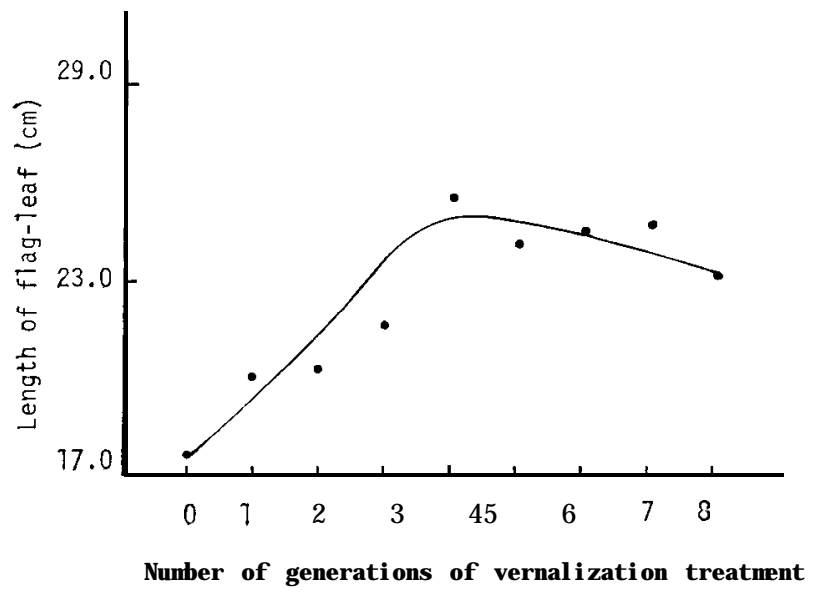

Fig. 3. Length of flag-leaf in $\mathrm{V}_{0}-\mathrm{V}_{8}$ lines (1971). 
1970 and $\mathrm{V}_{0}-\mathrm{V}_{8}$ lines in 1971. In both years the rate of increase in plant height in successive generations was almost the same. The saturated generation was 5th generation in 1970 and 4th generation in 1971.

Fig. 3 shows length of flag leaf in $V_{0}-V_{8}$ lines in 1971, this character also showed a steady increase in successive generations and the saturated generation was the 4th generation. After saturated generation, the trend of decrease in both characters in more successive generations was recognized.

Table 1. Comparison of ear in $\mathrm{V}_{0}-\mathrm{V}_{4}$ lines (1967).

\begin{tabular}{|c|c|c|c|c|c|c|}
\hline Line & $V_{0}$ & $V_{1}$ & $\mathrm{~V}_{2}$ & $\mathrm{~V}_{3}$ & $\mathrm{~V}_{4}$ & $\begin{array}{l}\text { L.S. D. } \\
(5 \%)\end{array}$ \\
\hline $\begin{array}{l}\text { Ear length }(\mathrm{cm}) \\
\text { Length of upper } 5 \text { nodes of ear }(\mathrm{mm}) \\
\text { No. of spikelet }\end{array}$ & $\begin{array}{r}9.3 \\
18.5 \\
19.6\end{array}$ & $\begin{array}{l}10.2 \\
19.3 \\
19.6\end{array}$ & $\begin{array}{l}11.1 \\
19.7 \\
19.4\end{array}$ & $\begin{array}{l}11.0 \\
20.5 \\
19.5\end{array}$ & $\begin{array}{l}12.1 \\
22.5 \\
19.4\end{array}$ & $\begin{array}{r}0.5 \\
1.2 \\
\text { N.S. }\end{array}$ \\
\hline
\end{tabular}

The length of ear in main stem of $\mathrm{V}_{0} \cdots \mathrm{V}_{4}$ lines in 1967 is shown in Table 1 and Fig. 4. The length of ear of each line revealed that the length of ear increased corresponding to the increasing number of treated generations.

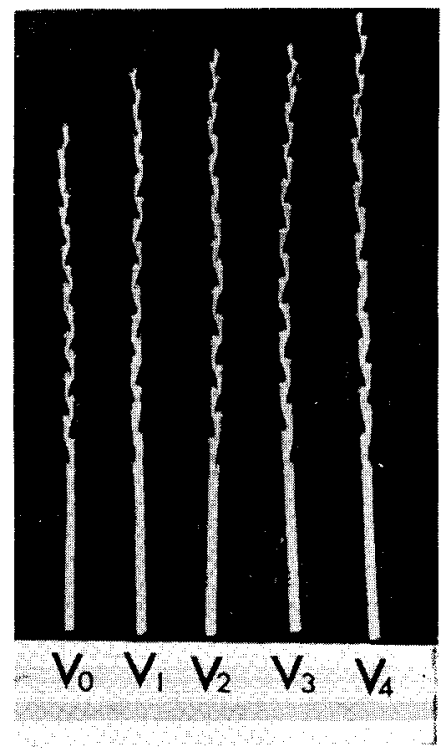

Fig. 4. Comparison of ear in $\mathrm{V}_{0}-\mathrm{V}_{4}$ generations (1967).

Observation on spikelet number (node number) of the ear was made for determining the causes of the elongation of ear, but no significant differences in the number of spikelets were seen. Therefore, it was clear that the cause of

Table 2. Comparison of ear in $\mathrm{V}_{0} \mathrm{R}_{1}-\mathrm{V}_{4} \mathrm{R}_{1}$ lines (1968).

\begin{tabular}{|c|c|c|c|c|c|c|}
\hline Line & $\mid V_{0} R_{1}$ & $\mathrm{~V}_{1} \mathrm{R}_{1}$ & $\mathrm{~V}_{2} \mathrm{R}_{1}$ & $\mathrm{~V}_{3} \mathrm{R}_{1}$ & $\mathrm{~V}_{4} \mathrm{R}_{1}$ & $\begin{array}{l}\text { L.S.D. } \\
\text { (5\%) }\end{array}$ \\
\hline $\begin{array}{l}\text { Ear length }(\mathrm{cm}) \\
\text { Length of upper } 5 \text { nodes of ear }(\mathrm{mm}) \\
\text { No. of spikelet }\end{array}$ & $\begin{array}{l}11.4 \\
20.4 \\
20.7\end{array}$ & $\begin{array}{l}11.8 \\
21.0 \\
20.7\end{array}$ & $\begin{array}{l}11.8 \\
21.0 \\
20.7\end{array}$ & $\begin{array}{l}12.2 \\
21.6 \\
20.4\end{array}$ & $\begin{array}{l}12.8 \\
26.0 \\
20.9\end{array}$ & $\begin{array}{l}0.4 \\
0.5 \\
\text { N.S. }\end{array}$ \\
\hline
\end{tabular}


the elongation of the ear lied in the elongation of the distance between the spikelets (nodes), and it was observed that the length of upper 5 nodes on rachis was elongated and this elongation was remarkable in the $V_{4}$ line.

This cumulative trend can be recognized in Table 2, as a residual effect in $\mathrm{V}_{0} \mathrm{R}_{1}-\mathrm{V}_{4} \mathrm{R}_{1}$ lines, which were non-treated lines derived from above mentioned $\mathrm{V}_{0}-\mathrm{V}_{4}$ lines (1967).

\section{(2) On the reversibility of after-effects}

The cumulative after-effects on ear length were reversible under the nontreatment condition, however, complete reversibility of after-effect required at least three generations under non-treatment condition.

To assay the reversibility of the after-effect of vernalization, 4 lines, which had been grown for 1-4 consecutive generations under the vernalization condition, were grown for 1,2 or 3 generations, respectively, under non-treatment condition.

Table 3. Ear length $(\mathrm{mm})$ in $\mathrm{V}_{\mathbf{0}}-\mathrm{V}_{\mathbf{4}}$ lines under non-treatment condition.

\begin{tabular}{|c|c|c|c|c|c|c|}
\hline Line & $\mathrm{V}_{0}$ & $\mathrm{~V}_{1}$ & $\mathrm{~V}_{2}$ & $\mathrm{~V}_{3}$ & $\mathrm{~V}_{4}$ & L.S.D. (5\%) \\
\hline $\begin{array}{ll}\mathrm{R}_{1} & (1969) \\
\mathrm{R}_{2} & (1970) \\
\mathrm{R}_{3} & (1971)\end{array}$ & $\begin{array}{l}90.1 \\
88.7 \\
75.1\end{array}$ & $\begin{array}{l}94.7 \\
89.2 \\
75.0\end{array}$ & $\begin{array}{l}95.8 \\
85.4 \\
76.0\end{array}$ & $\begin{array}{l}95.9 \\
86.3 \\
73.7\end{array}$ & $\begin{array}{l}99.0 \\
87.1 \\
74.2\end{array}$ & $\begin{array}{l}3.1 \\
\text { N.S. } \\
\text { N.S. }\end{array}$ \\
\hline
\end{tabular}

Table 4. Length $(\mathrm{mm})$ of upper 5 nodes in ear of $\mathrm{V}_{0}-\mathrm{V}_{4}$ lines under non-treatment condition.

\begin{tabular}{c|c|c|c|c|c|c}
\hline Line & $\mathrm{V}_{0}$ & $\mathrm{~V}_{1}$ & $\mathrm{~V}_{2}$ & $\mathrm{~V}_{3}$ & $\mathrm{~V}_{4}$ & L.S.D. (5\%) \\
\hline $\mathrm{R}_{1}(1969)$ & 16.4 & 17.5 & 17.9 & 17.9 & 18.9 & 0.8 \\
$\mathrm{R}_{2}(1970)$ & 21.3 & 21.6 & 22.6 & 21.9 & 23.1 & 0.4 \\
$\mathrm{R}_{3}(1971)$ & 19.5 & 19.4 & 20.1 & 19.9 & 21.0 & 0.9 \\
\hline
\end{tabular}

Table 3 shows the ear length of main stem. The effect of vernailzation treatment on ear length disappeared in the 2 nd generation under non-treatment condition, but the effect in length of upper 5 nodes on rachis of the line descended from $\mathrm{V}_{4}$ line decreased but did not disappear up to the 3rd generation (Table 4).

\section{DISCUSSION}

The causes of elongation of the ear with the vernalization treatment, especially the mechanism for the elongation of the distance between the spikelets of the upper parts of the ear are still unknown.

Mention of the question wheather the cumulative tendency of the after-effect was caused by the selection, as it was already considered with the materials and methods section of this paper, seems to deny any such possibility, but further consideration is necessary. For clarifying this point investigations are 
being continued with many varieties.

In this experiment (8 successive generations), the 'saturation' of after-effects as reported by Highkin (1958) was observed.

\section{REFERENCES}

Highkin, H. R. 1958. Temperature-induced variability in peas. Amer. J.Bot. 45: 626-631. Ikeda, H. 1968. An analytical consideration of the adaptation process in spring wheat by the successive vernalization treatment. Jap. J. Michurin Biol. 4: 42-45. (In Japanese)

Komastuzaki, A., Isayama, E. and Ogawa, S. 1961. After-effect of vernalization of wheat seed on the crop in the succeeding generation. Japan. J. Breed. 11: 213-219. (In Japanese)

Suetsugu, I., Kamano, S. and Yoshida, K. 1967. Embryogenic ecology of soybean varieties and its after-effects. II On the after-effects of soybean seeds developed under specially controlled conditions for long successive generations. Japan. J. Breed. 17: 212220. (In Japanese)

Went, F. W. 1959. Effects of emvironment of parent and grandparent generation on tuber production by potatoes. Amer. J. Bot. 46: 277-282. 